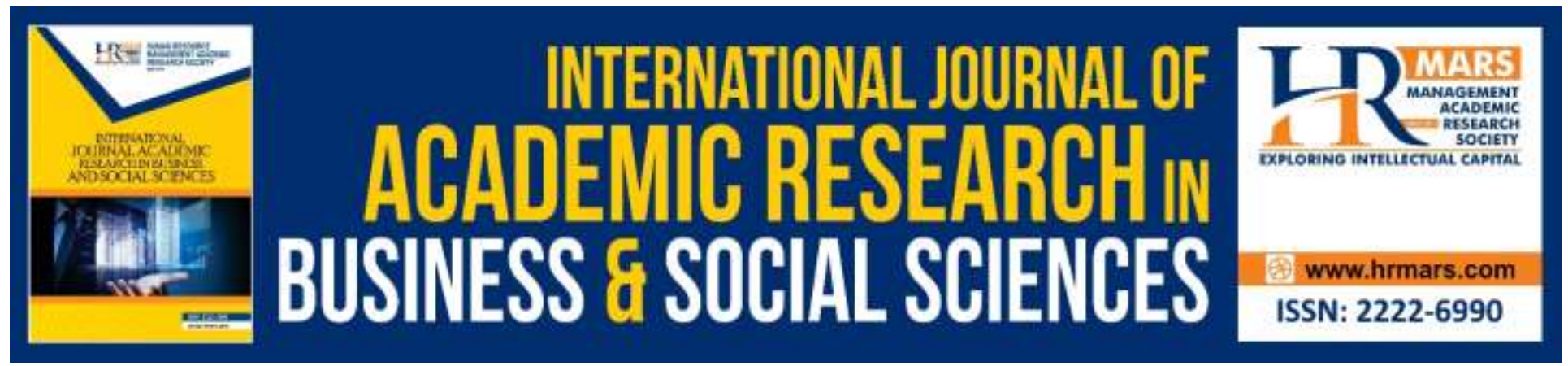

\title{
Factors Influenced the Cloud Computing Adoption in Teaching and Learning Process
}

\begin{abstract}
Maziah Mahmud, Nor Hazreeni Hamzah, Shamsunarnie Mohamed Zukri, Wan Fairos Wan Yaacob and Jusoh Yacob
\end{abstract}

To Link this Article: http://dx.doi.org/10.6007/IJARBSS/v9-i13/6475

DOI:10.6007/IJARBSS/v9-i13/6475

Received: 04 August 2019, Revised: 27 August 2019, Accepted: 02 September 2019

Published Online: 23 September 2019

In-Text Citation: (Mahmud, Hamzah, Zukri, Yaacob, \& Yacob, 2019)

To Cite this Article: Mahmud, M., Hamzah, N. H., Zukri, S. M., Yaacob, W. F. W., \& Yacob, J. (2019). Factors Influenced the Cloud Computing Adoption in Teaching and Learning Process. International Journal of Academic Research in Business and Social Sciences, 9(13), 284-290.

Copyright: (C) 2019 The Author(s)

Published by Human Resource Management Academic Research Society (www.hrmars.com)

This article is published under the Creative Commons Attribution (CC BY 4.0) license. Anyone may reproduce, distribute, translate and create derivative works of this article (for both commercial and non-commercial purposes), subject to full attribution to the original publication and authors. The full terms of this license may be seen at: http://creativecommons.org/licences/by/4.0/legalcode

Special Issue: Revolutionizing Education: Challenges, Innovation, Collaboration, 2019, Pg. 284 - 290 http://hrmars.com/index.php/pages/detail/IJARBSS

Full Terms \& Conditions of access and use can be found at http://hrmars.com/index.php/pages/detail/publication-ethics 


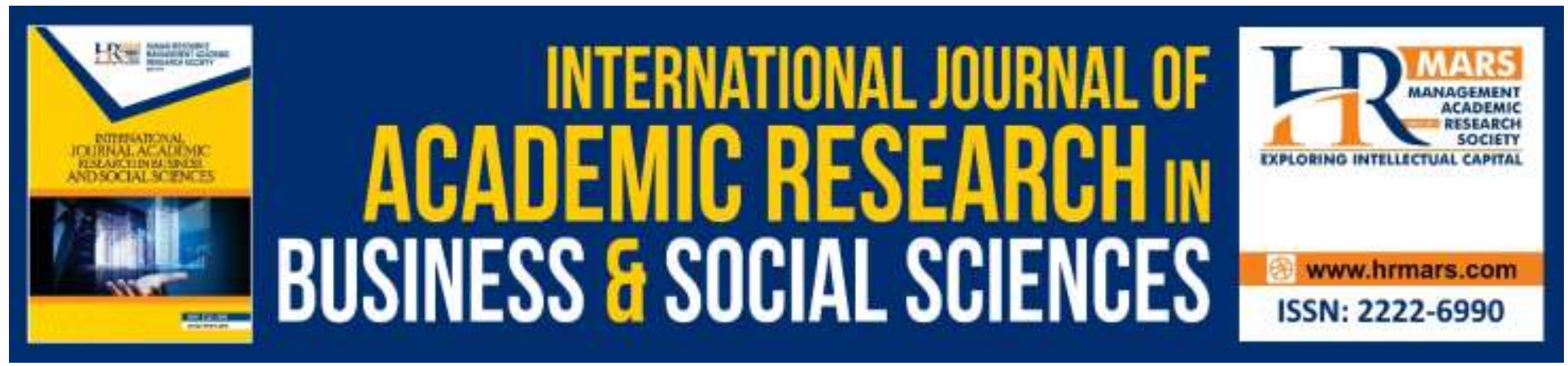

\title{
Factors Influenced the Cloud Computing Adoption in Teaching and Learning Process
}

\author{
Maziah Mahmud', Nor Hazreeni Hamzah¹, Shamsunarnie \\ Mohamed Zukri ${ }^{1}$, Wan Fairos Wan Yaacob ${ }^{1}$ and Jusoh Yacob ${ }^{2}$ \\ ${ }^{1}$ Faculty of Computer and Mathematical Sciences, UiTM Cawangan Kelantan, Malaysia \\ ${ }^{2}$ Kolej Teknologi Darul Naim, Kelantan \\ Email:maziah740@ kelantan.uitm.edu.my,reeni683@kelantan.uitm.edu.my, \\ shamsunarnie077@kelantan.uitm.edu.my,wnfairos@ kelantan.uitm.edu.my. \\ jyacobuitm@gmail.com
}

\begin{abstract}
Cloud computing plays a major role's in today's technology sector. Education sector is not out of this phenomenon. Cloud computing is transforming teaching and learning, inside and outside the classroom. This study aims to investigate the prevalence of adoption of cloud computing among Universiti Teknologi MARA (UITM) academicians, students and staffs. Besides, this study also was conducted to determine factors that influenced the decision of adopting cloud computing in teaching and learning. A validated administered questionnaire was transformed into Google Form to ease the data collection process. Students's t-test and Chi -Square test were used for univariate data analysis. For multivariate data analysis, multiple binary logistic regression analysis was performed. The results found that 67.1 percent of respondent adopting the cloud computing in teaching and learning process. There was a significant difference on mean scores of usage variables by adoption of cloud computing status. The adoption of cloud computing in teaching and learning status of respondents do not have a significant association with gender. Furthermore, only variable of usage was significantly influenced the adoption of cloud computing in teaching and learning. In conclusion, it is recommended to motivate the academicians, students and staffs to maximize the usage of cloud computing to ensure that the adopting of cloud computing was applied in learning and teaching process.

Keywords: Cloud Computing, Awareness, Challenges, Factor Analysis, Teaching And Learning.
\end{abstract}

\section{Introduction}

Cloud Computing allows the users to access web-based applications via their web browsers. It also enables users, with various computing capabilities to store and process data in the cloud to 
make the mechanisms of data access more efficient and reliable. By using computer technology in the classroom, educators are allowed to collaborate with their students in efficient way. They can collaborate between educators and students or among students themselves. Collaboration is defined as individuals working together in groups towards the shared goal collectively. While, collaborative writing is also defined as projects where written works are created by multiple people together. In a true collaborative environment, each contributor has an almost equal ability to add, edit, and remove text. Collaborative writing tools can provide substantial advantages to projects ranging from increased user commitment to easier, more effective and efficient work processes. The way of collaborating on documents did not change with the introduction of the desktop computer into mainstream society. With the old technology of internal and external hard drives, authors save documents on a hard drive, and when it comes to collaborating on a document, the author emails a copy an attachment to a co-author or editor.

Hamzah et.al (2017) in their research found that computer technology has become an essential tool for educators to ensure that teaching and learning (T\&L) process becomes more interesting and effective. The use of Cloud Computing will enhance T\&L process which is differ to traditional techniques. Cloud Computing is the interactive way for educators to collaborate with students along T\&L process. According to Al-Zoube (2009), Cloud Computing technologies enable institutions that do not have the technical expertise to support their own infrastructure to get access to computing on demand. Cloud Computing makes it possible for almost anyone to deploy tools that can scale on demand to serve as many users as desired. Service providers enjoy greatly simplified software installation and maintenance and centralized control over versioning; consumers can access the service anytime, anywhere, share data and collaborate more easily and keep their data stored safely in the infrastructure.

The impact of Cloud Computing is that the adoption of Cloud Computing has a significant impact on cost effectiveness where it can reduce development team cost, technical support team cost, burden of daily backup management and cost of overall project expenditure as stated in Ahmed (2015), Akin et.al (2014), Rao et.al (2010) and Al-Zoube (2009). Furthermore, Akin et.al (2014) found that the adoption of Cloud Computing revealed that it will enhanced availability, low environmental impact, reduced IT complexities, mobility, scalability, increased operability and reduced investment in physical asset.

Model of Cloud Computing are include Infrastructure as a Service (laaS), Platform as a Service (PaaS) and Software as a Service (SaaS). They are called as Services Oriented Architecture. The illustration of the layers for the Services Oriented Architecture was shown in Fern'andez et.al (2012). Based on this model, a study on awareness and adoption of cloud computing among academicians, staffs and students of UiTM was conducted. This paper will review the challenges confronting the adoption of Cloud Computing in data insecurity, unsolicited advertisement, lockin, reluctance to eliminate staff positions, privacy concerns, reliability challenge, regulatory compliance concerns/user control and institutional culture/resistance to change in technology. This possible challenges can be factorized in awareness and adoption, assessment on the usage, 
assessment on the benefits and assessment on the challenges of using Cloud Computing. It will help in empowering the teaching and learning and indirectly in the improvement of student's soft skills.

\section{Materials and Methods}

This survey was conducted among Universiti Teknologi MARA (UiTM) academicians, students and staffs, from $1^{\text {st }}$ July to $15^{\text {th }}$ August, 2018. A total of 76 respondents were identified as respondent. A validated administered questionnaire was transformed into Google Form to ease the data collection process. The questionnaire was adapted from O.C.Akin et.al (2014). The questionnaire consisted of five sections which were demographics profiles (Section A), assessment on awareness and adoption (Section B), assessment on the usage (Section C), assessment on the benefits (Section D) and assessment on the challenges (Section E) of using Cloud Computing. The questionnaire was pre tested on 40 academicians of UiTM Cawangan Kelantan. Based on this pre tested study, some of the questions were added and modified for this current study section. All the assessment on Section $C$ to Section E involved the use of a total of 10 points as ratings. Respondent were asked to rate their assessment by providing a simple general rating, 1 to 10, in which e.g.: 1 equal to strongly disagree and 10 representing strongly agree.

\section{Statistical Analysis}

The reliability of questionnaire was tested by using the reliability analysis (Cronbach Alpha). All descriptive results for continuous variables were given as mean and standard deviation. For categorical variables, frequency and percentages were used to describe the data. In univariate analysis, the comparison of data between two groups ("adopt cloud computing" and "not adopt cloud computing") was performed using Students's t-test, Chi -Square test or Fisher's Exact test as appropriate with the level of significance at 0.05 . In details, Students 's ttest was used to determine whether the scores of the interest variable (Usage, Benefits and Challeges) were from the same population or not. If the assumption of Students's t-test were not met, Mann-Whitney $U$ test were use. Chi Square test was used to test for independence or relatedness for data measured on scales and Fi sher's Exact was used if assumptions for ChiSquare tests were not met. Prevalence was calculated for the adoption of cloud computing. A multiple binary logistic regression analysis were used to investigate factors that influenced the decision of adopting cloud computing in teaching and learning. The influenced factors, which were age, gender, usage, benefits and challeges were studied. A two-sided hypotheses testing were used in all analysis with $p<0.05$ was considered statistically significant. All the analyses were done using IBM SPSS version 2.0.

\section{Results}

\section{Descriptive Statistics}

The Cronbach Alpha for Section C, D and E was $0.918,0.962$ and 0.931 respectively which indicated the instrument was reliable for data collection. A total of 76 respondents were completed the questionnaire for this study. The respondent consisted $61.8 \%$ academicians, $28.9 \%$ students and $9.2 \%$ staffs. Most of the respondent were from Fakulti Sains Komputer dan Matematik (42.0\%) and Fakulti 
INTERNATIONAL JOURNAL OF ACADEMIC RESEARCH IN BUSINESS AND SOCIAL SCIENCES

Vol. 9, No. 13, Special Issue: Revolutionizing Education: Challenges, Innovation, Collaboration., 2019, E-ISSN: 2222-6990 @ 2019 HRMARS

Pengurusan Perniagaan (14.6\%). The rest of respondent were from various faculty and department. Demographic profiles, usage, benefits and challenge information of respondents were presented in Table 1.

\section{Univariate Analysis}

Mean score for usage, benefits and challenges assessment by respondents were $7.8,8.1$ and 7.1 respectively (Table 1). This result described that most of the respondent agreed on usage, benefits and challenges of cloud computing adoption in teaching and learning process. In addition, the result showed that there was a significant difference on mean scores of usage variables between adopt and not adopt groups. Otherwise the mean age, benefits and challenges were not statistically difference by adoption status.

Table 1: Demographic, usage, benefits and challenges assessment of respondents

\begin{tabular}{|c|c|c|c|c|c|c|}
\hline Variables & $\begin{array}{c}n \text { or } n \\
(\%)^{a}\end{array}$ & Mean (SD) & $\begin{array}{c}\text { Adopt } \\
\text { Mean }(S D) \\
\text { or } n(\%)^{\mathbf{b}} \\
\end{array}$ & $\begin{array}{c}\text { Not adopt } \\
\text { Mean }(S D) \\
\text { or } n(\%)^{b}\end{array}$ & $\begin{array}{c}t \text {-Stats }(d f) \\
\text { or } \\
\chi^{2} \text {-Stats }(d f)\end{array}$ & $\begin{array}{c}p- \\
\text { value }\end{array}$ \\
\hline Age (year) & 76 & 35.9 (10.63) & 36.1 (10.03) & 35.5 (11.98) & $0.221(74)$ & 0.825 \\
\hline Usage & 76 & $7.8(1.81)$ & $8.1(1.56)$ & $7.1(2.12)$ & $2.388(74)$ & 0.019 \\
\hline Benefits & 76 & 8.1 (1.68) & 8.3 (1.37) & $7.5(2.11)$ & $1.749(34.1)$ & 0.089 \\
\hline Challenges & 76 & $7.1(1.85)$ & $6.9(2.09)$ & $7.3(1.23)$ & $-0.919(71.5)$ & 0.361 \\
\hline Gender & & & & & $0.053(1)$ & 0.818 \\
\hline Male & $\begin{array}{c}26 \\
(34.2)\end{array}$ & - & $17(65.4)$ & 9 (34.6) & & \\
\hline Female & 50 & - & $34(68.0)$ & $16(32.0)$ & & \\
\hline
\end{tabular}

(65.8)

${ }^{\mathrm{a}}$ Row percent ${ }^{\mathrm{b}}$ Column percent

Table 1 shows that the adoption of cloud computing in teaching and learning status of respondents do not have a significant association with gender since the $p$-value was greater than 0.05 .

\section{Prevalence of Adopting Coud Computing}

There was $67.1 \%(n=51)$ respondent adopting the cloud computing in teaching and learning process whereas $61.8 \%(n=47)$ were lecturer, $28.9 \%(n=22)$ were student and $9.2 \%(n=7)$ were staff. Those who adopt IAAS, SAAS and PAAS were $56.9 \%, 31.4 \%$ and $11.8 \%$ respectively. 
INTERNATIONAL JOURNAL OF ACADEMIC RESEARCH IN BUSINESS AND SOCIAL SCIENCES

Vol. 9, No. 13, Special Issue: Revolutionizing Education: Challenges, Innovation, Collaboration., 2019, E-ISSN: 2222-6990 @ 2019 HRMARS

\section{Factors Associated with Adopting Cloud Computing}

Table 2 Associated factors of adopting cloud computing among 76 respondents

\begin{tabular}{clcc}
\hline Variable & Adjusted $O R(95 \% \boldsymbol{C l})$ & LR-stat. $(\boldsymbol{d} f)$ & $\boldsymbol{p}$-value \\
\hline Constant & -1.750 & $2.429(1)$ & 0.119 \\
Usage & $1.382(1.039,1.839)$ & $4.929(1)$ & 0.026 \\
\hline
\end{tabular}

${ }^{\mathrm{b}}$ Multiple binary logistic regression (Nagelkerke $R^{2}=0.096$ )

$O R=$ Odds Ratio $\mathrm{Cl}=$ Confidence Interval

Notes: The model fitness: Hosmer Lemeshow goodness-of-fit test ( $p=0.060)$; correctly classified $=68.4 \%$

Based on Table 2, only variable of usage was significant factor associated with adoption of cloud computing in teaching and learning. The model for the cloud computing adoption is given as Equation 1 below:

$$
\ln \left(\frac{p(\text { adopt cloud })}{p(\text { not adopt cloud })}\right)=-1.750+0.324 * \text { usage }
$$

From the Equation 1, the odd ratio for usage is 1.382 (ie $e^{0.324}=1.382$ ). This indicate that for every one unit increase in usage, the odds of adopting cloud computing in teaching and learning process among respondent increase by 1.382 times as compared to the one who are not adopt with cloud computing among academicians, students and staffs in UiTM (95\% Cl: 1.039, 1.839; $p=0.026)$.

\section{Discussion}

The prevalence of adoption of Cloud Computing among respondents in UiTM was 67.1\%, which was considered higher than the previous study done among public universities (O.C.Akin et.al, 2014). Based on the finding, most of the academicians, students and staffs in UiTM were comfort with IAAS in adopting Cloud Computing in their teaching and learning process. The study finding also showed that both, male and female respondent were adopting the Cloud Computing with higher percentage in their teaching and learning process. This study also suggests that only usage of Cloud Computing by the respondents was significantly influenced the decision of adopting Cloud Computing in teaching and learning. Otherwise, benefits and challenges were not statistically influenced the adoption decision. However, the small number of respondent might be influence the finding.

\section{Conclusion}

In conclusion, the prevalence of adoption of Cloud Computing among respondents in UiTM was found to be high enough to encourage other academician to considered the Cloud Computing as a main method of teaching and learning. It is recommended to motivate the academicians, students and staffs to maximize the usage of Cloud Computing to ensure that the adopting of Cloud Computing was applied in learning and teaching. Since the study only found one interest variable to be significantly influenced the adoption of Cloud Computing decision, it is recommended the future studies to improve the design of the studies and increased the sample size. 


\section{Acknowledgements}

A special gratitude to our group members inn stimulating, suggestions and encouragement on this project. Furthermore, we would like to acknowledge with much appreciation to UiTM for providing the research ARAS grant (600-IRMI/DANA 5/3/ARAS (0064/2016). We would like to extend our sincere thanks to all respondents who participated in this project.

\section{References}

Ahmed, F. F. (2015). Comparative analysis for cloud based e-learning. Procedia Computer Science, 65, 368-376.

Akin, O. C., Matthew, F., \& Comfort, D. (2014). The impact and challenges of cloud computing adoption on public universities in Southwestern Nigeria. International Journal of Advanced Computer Science and Applications (IJACSA), 5(8), 13-19.

Al-Zoube, M. (2009). E-Learning on the Cloud. Int. Arab J. e-Technol., 1(2), 58-64.

Bayramusta, M., \& Nasir, V. A. (2016). A fad or future of IT: A comprehensive literature review on the cloud computing research. International Journal of Information Management, 36(4), 635-644.

Fernandez, A., Peralta, D., Herrera, F., \& Benítez, J. M. (2012). An overview of e-learning in cloud computing. In Workshop on Learning Technology for Education in Cloud (LTEC'12) (pp. 3546). Springer, Berlin, Heidelberg.

Rao, N. M., Sasidhar, C., \& Kumar, V. S. (2012). Cloud computing through mobile-learning. arXiv preprint arXiv:1204.1594.

Hamzah, N. H., Mahmud, M., Zukri, S. M., Yaacob, W. F. W., \& Yacob, J. (2017). The Awareness and Challenges of Cloud Computing Adoption on Tertiary Education in Malaysia. In Journal of Physics: Conference Series (Vol. 892, No. 1, p. 012014). IOP Publishing. 